\title{
GLUCONEOGENIC SUPPLEMENTS DO NOT AFFECT PRODUCTION, REPRODUCTIVE TRAITS AND BLOOD METABOLITE OF HOLSTEIN COWS DURING THE TRANSITION PERIOD
}

\author{
Paulo Garcez de Oliveira ${ }^{1}$; Alexandre Vaz Pires ${ }^{1 *}$; Paula Marques Meyer ${ }^{1}$; Ivanete Susin ${ }^{1}$; Elias \\ Tunon Villarreta ${ }^{2}$; Paulo Henrique Mazza Rodrigues ${ }^{3}$; Flávio Augusto Portella Santos ${ }^{1}$ \\ ${ }^{1}$ USP/ESALQ - Depto. de Zootecnia - C.P. 9 - 13418-900 - Piracicaba, SP - Brasil. \\ ${ }^{2}$ Fundação de Ensino Octávio Bastos - Depto. de Clínica e Cirurgia, Av. Dr Octávio Bastos, s/n - 13870-000 - São \\ João da Boa Vista, SP - Brasil. \\ ${ }^{3}$ USP/FMVZ - Depto. de Nutrição e Produção Animal, C.P. 23 - 13630-000 - Pirassununga, SP - Brasil. \\ *Corresponding author <alvpires@esalq.usp.br>
}

ABSTRACT: The use of gluconeogenic supplements for dairy cows during the transition period has produced contradictory responses in the literature, making it difficult to recommend them. The objective of this trial was to evaluate supplementation with propylene glycol (PG), calcium propionate (CP), and "Dairy Power Drench $^{\circledR}$ " (DR) on the transitional period of Holstein cows. Parameters studied were variation of body condition score (BCS), body weight (BW), milk production (MP), reproductive efficiency and nonesterified fatty acid concentration (NEFA). One hundred and sixty five animals from two commercial herds were used. Treatments

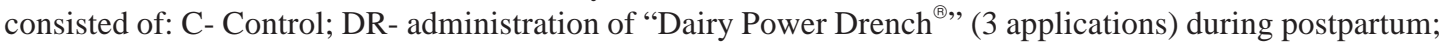
CP- daily administration of calcium propionate (500 g); PG- daily administration of propylene glycol (500 $\mathrm{mL}$ ). Variation sources studied were the effect of treatments and blocks as function of farm and parity. No interaction between time (weeks) and treatments, or treatment effects, were found for BCS. However, there was a quadratic effect of time. Body weight and its variation were not affected by treatment nor by the time $\times$ treatment interaction. However, a quadratic effect of time was observed. An interaction time $\times$ treatment was observed on MP, but possible differences within each week were not detected. Treatments also did not affect reproductive efficiency parameters. On average, the number of days to first detected postpartum estrus was 69.5, with 2.23 services per conception and 172.6 days open. The mean concentration of nonesterified fatty acids was $376.6 \mathrm{mmol} \mathrm{L}^{-1}$ and no effect of the interaction time $\times$ treatment, or of treatment, was observed. However, a linear effect was observed with time, with a decrease of $48.2 \mathrm{mmol} \mathrm{L}^{-1}$ per week.

Key words: propylene glycol, calcium propionate, dairy power drench, Holstein cow, reproductive efficiency

\section{PRODUTOS GLICONEOGÊNICOS NÃO AFETAM RESPOSTAS PRODUTIVAS, REPRODUTIVAS E SANGÜÍNEA DE VACAS HOLANDESAS EM TRANSIÇÃO}

RESUMO: O uso de produtos gliconeogênicos para vacas leiteiras no período de transição tem gerado respostas contraditórias na literatura, dificultando a sua recomendação. O objetivo deste experimento foi avaliar a suplementação de propileno glicol (PG), propionato de cálcio (PC) e “Dairy Power Drench " (DR) no período de transição de vacas leiteiras sobre a variação do escore da condição corporal (ECC), peso vivo (PV), produção de leite (PL), eficiência reprodutiva e concentração plasmática dos ácidos graxos livres (AGL). Foram utilizadas 165 fêmeas de dois rebanhos comerciais. Os tratamentos foram: C- Controle; DR- 3 aplicações de “Dairy Power Drench ${ }^{\circledR}$ ” no pós-parto; PC- 500 g diários de PC e PG- 500 mL diários de PG, até o $50^{\circ}$ dia pós-parto, em média. As causas de variação estudadas foram efeito de tratamento e efeito dos blocos formados em função da fazenda e do número de partos. Não foi observado efeito de interação de tempo (semanas) × tratamento ou de tratamento sobre ECC. Entretanto, houve efeito quadrático de tempo. Para o PV e variação diária de PV não foi observado efeito dos tratamentos, nem interação entre tempo $\times$ tratamento. Entretanto, apresentaram efeito quadrático de tempo. Para PL, houve efeito de interação tempo $\times$ tratamento. Porém, dentro de cada semana, as possíveis diferenças não foram detectadas. Os tratamentos não afetaram os parâmetros de eficiência reprodutiva. Encontraram-se, em média, 69,5 dias para o aparecimento do primeiro cio, 2,23 serviços por concepção e 172,6 dias para o período de serviço. As concentrações médias dos AGL foram de 376,6 mmol L ${ }^{-1}$, não se observando efeitos de tempo $\times$ tratamento ou de tratamento. Porém, apresentaram efeito linear de tempo, decrescendo $48,2 \mathrm{mmol} \mathrm{L}^{-1}$ por semana.

Palavras-chave: propileno glicol, propionato de cálcio, dairy power drench, vacas em transição, eficiência reprodutiva

Sci. Agric. (Piracicaba, Braz.), v.61, n.4, p.376-385, July/August 2004 


\section{INTRODUCTION}

Milk production in recent decades has experienced marked increases as a result of intense genetic selection, advances in nutritional management, improvements in disease control, and other management practices (Miyoshi et al., 2001). The globalization of the economy has facilitated the commercialization of semen, embryos, and animals, and this has contributed to increase the world milk production, especially regarding genetic materials of Canadian and American origin (Philipson, 1990). A few basic points to observe to achieve high efficiency in intensive production systems are the use of specialized animals, and sanitary, nutritional and reproductive management practices as near as possible to the ideal, thus offering adequate comfort conditions, so the animals can respond with high yields. Management, in addition to the environment are the main causes of variation in reproduction and milk yield (Nebel \& McGillard, 1993); milk production and reproductive performance play the most relevant roles in determining the profitability of dairy herds (Arbel et al., 2001).

Cow's efficiency in the subsequent lactation is determined during the transition period, and problems during this period result in losses from 4.5 to $9.0 \mathrm{~kg}^{\text {day }}{ }^{-1}$ in the peak of lactation, representing economic losses of U\$300 to U\$600 per lactation under consideration (Drackley, 1999). The transition period, according to Schlatter (1997), varies from three weeks before calving to different postpartum periods. This postpartum period may vary from three weeks or until the cow reaches lactation peak, with variations according to the management adopted for the animal. This period is characterized by great metabolic stress, and manifested by a decrease in voluntary feed intake, intense mobilization of body reserves, and increase in nutritional requirements, with consequences in yield and reproduction.

Nonesterified fatty acids (NEFA) are the main source of energy during the end of gestation and the beginning of lactation. Its concentrations in the plasma obey a growing pattern starting on the third prepartum week, with a peak near calving, decreasing through lactation (Drackley, 1998).

On the other hand, serum insulin concentrations follow an inverse pattern, decreasing considerably as calving approaches (Studer et al., 1993). Therefore, feeding the cow during this period is a challenge, since this stage is marked by endocrine changes, responsible for preparing the cow for the final growth of the fetus, calving, and lactogenesis (Grummer, 1995).

Even though a well-balanced diet may reduce problems in the transition period, the program can be compromised if a decrease in intake occurs, which leads to dietary deficiencies in energy and other nutrients. In this context, forced oral administration of nutrients could be a useful tool to increase blood concentrations of calcium, minimize energy deficiency, rehydrate the animal and stimulate ruminal fermentation (Stokes \& Goff, 2001). Studer et al. (1993) demonstrated that the administration of energy supplementation in the transition period reduced the plasma concentrations of ketone bodies and FFA, and increased the concentrations of insulin, during the supplying period.

Researches have been conducted to find energy alternatives that would diminish the energy deficiency in the transition period, allowing the animals to show yields and reproduction compatible with their potential. In this sense, the use of plant and animal fats, propylene glycol, sodium propionate, calcium propionate, and ionophores have been evaluated. Another alternative has been the use of "Dairy Power Drench ${ }^{\circledR}$, , even though no literature data is available about this product.

Therefore, the objective of this study was to evaluate organic responses to the use of neoglycogenic substances on physical condition, yield, reproduction, and blood parameter, when administered daily and orally to dairy cows, from two weeks before the estimated calving date until seven weeks postpartum (calcium propionate and propylene glycol), and three postpartum applications, on consecutive days, beginning on the calving day (Dairy Power Drench ${ }^{\circledR}$ ).

\section{MATERIAL AND METHODS}

Trials were carried out at two commercial doing farms (Holstein), located Araras (Farm 1) and Engenheiro Coelho (Farm 2), State of São Paulo, Brazil. One hundred and sixty five purebred and crossbred Holstein animals, 132 cows and 33 heifers, with calvings between March 15 and June 15, 1999 were used. Data collection extended from March 15 to August 12, 1999. Animals were managed under "free-stall" feedlot systems and total mixed ration (TMR) programs. Animals were not separated from the others and the management system adopted by each property was obeyed.

\section{Experimental treatments consisted of a control and three application protocols:}

Treatment 1 (control) - this group consisted of 31 cows and ten heifers submitted to the same management conditions as the animals that received the treatments.

Treatment 2 - oral administration of "Dairy Power Drench $^{\oplus 1 \text { ” }}$ to 42 animals (31 cows and 11 heifers), which received the treatments according to the manufacturer's recommendations: three applications, the first on the day of calving and the other two on the two

$\overline{{ }^{1}}$ The use and references to the commercial product Dairy Power Drenchâ do not imply endorsement by the authors.

Sci. Agric. (Piracicaba, Braz.), v.61, n.4, p.376-385, July/August 2004 
consecutive days. The product, sold in 500 g packs, was diluted in 25 to 30 liters of warm water and administered orally with a feeding catheter. Product composition, according to the manufacturer, is: yeast (Yea-Sacc), calcium carbonate, sodium bicarbonate, potassium chloride, cobalt sulfate, magnesium sulfate, chelated chromium, Bcomplex vitamins, propylene glycol, dextrose, and flavorants.

Treatment 3 - daily oral administration of propylene glycol (500 ml day ${ }^{-1}$ ) to 43 animals (33 cows and ten heifers), from thirteen days before the estimated calving date until 49 days postpartum. Administration was done with the help of an extra person, always in the morning.

Treatment 4 - daily oral administration of $500 \mathrm{~g}$ calcium propionate to 39 animals (37 cows and two heifers), from 11 days before the estimated calving date until 51 days postpartum. The $500 \mathrm{~g}$ of product were placed in 1-L glass bottles and the volume was completed to 1 $\mathrm{L}$, agitated to homogeneize the mix and provided to the animals at the same times as in the previous group. Obs.: in this group two heifers died and one cow had health problem due to product aspiration.

Body condition score (BCS) was evaluated weekly, with a scale from 1 (thin) to 5 (obese) 0.25 point intervals were adopted (Wildman et al., 1982). Body score variation was obtained from the difference between BCS in week six and week one for each animal.

Body weight was determined with a weight tape, on the same day as the body condition evaluation, always by the same person, to avoid possible assessor interferences. Body weight variation was obtained from the difference between weight in the $6^{\text {th }}$ and $1^{\text {st }}$ weeks for each animal. The daily variation in body weight corresponds to the daily weight loss during the experimental period. Animals were milked three times a day and milk yield was measured individually once a week for all animals.

Blood was sampled once a week in "vacuntainer" tubes, containing potassium oxalate and sodium fluoride, for nonesterified fatty acid (NEFA) determination. Samples $(n=2)$ were placed in an isothermal box until they arrived at the centrifugation site, which took approximately 3 hours, and were then centrifuged at $3000 \times \mathrm{g}$ for 20 minutes. Plasma was placed in Eppendorf tubes, $(\mathrm{n}=2)$ and stored in freezer at $-20^{\circ} \mathrm{C}$ for later analysis. Chemical analyses of nonesterified fatty acids were performed with the NEFA C KIT (WAKO Chemicals, Code no. 994-75409E). This test is based on the colorimetric enzymatic method (D.L. Palmquist, 1999; personal communication) adapted for use with microtitration plates, and later reading on an "Elisa Reader" device, with a 550 nm filter, results presented as micromoles per liter.

Number of days to first postpartum estrus, days open, and number of services per conception were also evaluated. Heat was detected twice a day by visual observation.
Samples of TMR were collected monthly, and at every two collections a sample was taken and stored at $-18^{\circ} \mathrm{C}$ for later chemical analysis, which was performed in the chemical analysis laboratory of AGRIBRANDS; the DM, CP, EE, CF, ash, Ca and P analyses were performed according to AOAC (1985); the NDF and ADF analyses were performed according to Van Soest et al. (1991). Chemical composition of diets is presented in Table 1.

Data were submitted to analysis of variance, with separation, as causes of variation, of the treatment effects and effects of blocks formed as a function of farm (Farm 1 and 2) and number of calvings (primiparous or multiparous). Analyses corresponding to milk yield values, body condition scores, body weight, daily variation of body weight, and nonesterified fatty acids were performed as previously described, but added of split-plot in time factor (weeks), corresponding to the several weekly data collection moments. Probabilities of interactions with time were determined by the Greenhouse-Geisse test, using the "REPEATED" command generated by the GLM procedure (PROC GLM) (SAS Institute Inc., 1985). Analyses by time were only performed when interactions between time and treatments were significant. The time effect evaluation within each treatment was performed by regression, using polynomial contrasts (PROC GLM). In the presence of linear or quadratic effects, the corresponding regression equation and coefficient of determination $\left(R^{2}\right)$ were obtained. In the presence of treatment effects, comparisons among treatment means were made by Tukey's test. A 5\% significance level was used in all tests performed.

\section{RESULTS AND DISCUSSION}

No interaction was found between farm and treatment in any of the studied variables. No interaction was observed between treatment and time for the body con-

Table 1 - Nutritional composition of diets at Farms 1 and 2, based on dry matter.

\begin{tabular}{lcc}
\hline Composition & Farm 1 & Farm 2 \\
\hline$\%$ & & \\
Dry matter & 51.65 & 44.45 \\
Crude protein & 16.96 & 17.08 \\
Ether extract & 4.76 & 4.58 \\
Crude fiber & 17.65 & 17.13 \\
Acid detergent fiber & 20.89 & 21.0 \\
Neutral detergent fiber & 36.34 & 39.1 \\
Ash & 6.0 & 6.63 \\
Ca & 0.9 & 0.81 \\
P & 0.32 & 0.29 \\
Nitrogen-free extractive & 54.65 & 54.59 \\
Total digestible nutrients & 71.71 & 71.33 \\
\hline
\end{tabular}


dition score variable. However, there was a quadratic effect of time on BCS $(P=0.0001)$ (Table 2 and Figure 1$)$. The equation was: $\mathrm{BCS}=3.433-0.135$ week +0.0118 week $^{2}$, and the point of inflexion of the curve was approximately the $40^{\text {th }}$ day, or $6^{\text {th }}$ week postpartum.

BCS for the group treated with propylene glycol was 3.0. This result is similar to the 3.11 value found by Fonseca (1997), who used only 15 doses of $300 \mathrm{~mL}$ propylene glycol, in daily administrations (from the fourth day prepartum until calving) and on alternate days (from the $10^{\text {th }}$ to the $6^{\text {th }}$ day prepartum and from calving to the $16^{\text {th }}$ day postpartum). Studer et al. (1993) also found similar results (BCS of 3.1) to those obtained in the present experiment for cows that received 1 L PG, daily, during the 7 days that preceded the estimated calving date. Likewise, Juchem (2000) provided a $300 \mathrm{~mL}$ dose daily and the animals showed a BCS of 3.13 in the sixth week of lactation, but showed higher milk yields ( $31.2 \mathrm{~kg}$ ) than animals in this trial. Perhaps the use of a smaller amount of propylene glycol might result in the same gluconeogenic effect, according to results obtained by Grummer et al. (1994), or maybe higher PG doses could decrease dry matter intake, according to Christensen et al. (1997).

Although the BCS data are different in different experiments, Gearhart et al. (1990) define the ideal body condition for cows at each lactation stage as that which optimizes milk yield, minimizes health problems and reproductive disorders, and maximizes the economic return of the farm. The ideal management for the cow during the transition period is one where calving occurs under good body condition, the incidence of fatty liver is reduced, dry matter intake is maximized, negative energy balance is not marked, and functions and reproductive efficiency are not reduced (Grummer, 1995).
Also, no difference $(P=0.7774)$ was verified in body condition variation among treatments during the experimental period (Table 2). On average, the cows lost 0.28 body score unit. Therefore, considering that loss of one unit represents $84 \mathrm{~kg}$ on body weight reduction (NRC, 2001), cows lost approximately $23.5 \mathrm{~kg}$ in 49 days after calving. The BCS for cows treated with calcium propionate was 3.2 at the end of the trial; this represents a 0.30 unit decrease when compared with the initial week, while Aslup \& Schlatter (1998) obtained a 0.22 decrease, despite the fact that those authors only used $114 \mathrm{~g}$ of the same product.

Weight loss did not differ ( $P=0.8698)$ among treatments (Table 3 and Figure 1), and no effect of the time and treatments interaction was observed $(P=0.8223)$. However, body weight showed a quadratic effect of time $(P=0.0001)$, as follows: $\mathrm{BW}=571.952-15.207$ week + 1.3729 week $^{2}$, the inflexion point of the curve occurring approximately on the $39^{\text {th }}$ day or in the $6^{\text {th }}$ and a half week after calving.

Mean cow's weight during the experimental period, considering all treatments, was $539.6 \mathrm{~kg}$ (558.2 in the beginning and $530.2 \mathrm{~kg}$ at the end). These results concerning weight loss are in agreement with Butler \& Canfield (1989), who stated that in the beginning of lactation the energy from feed intake is smaller than maintenance and production requirements. This is why cows with a high milk yield use their body reserves to supply such deficiencies, resulting in weight and body condition losses.

Cows that are obese at calving mobilize more body reserves during postpartum, because they are submitted to a more severe negative energy balance (Rukkwamsuk et al., 1998). During this stage, the use of

Table 2 - Effects of treatments on body condition score and its variation during the experimental period.

\begin{tabular}{|c|c|c|c|c|c|c|c|}
\hline \multirow[b]{2}{*}{ Week } & \multicolumn{4}{|c|}{ Treatment } & \multirow[b]{2}{*}{ Mean } & \multirow[b]{2}{*}{ SEM } & \multirow[b]{2}{*}{$P$} \\
\hline & $\mathrm{C}$ & DR & $\mathrm{CP}$ & PG & & & \\
\hline & \multicolumn{6}{|c|}{ Score } & \\
\hline 1 & 3.3 & 3.4 & 3.3 & 3.2 & 3.3 & 0.029 & 0.2886 \\
\hline 2 & 3.2 & 3.3 & 3.2 & 3.1 & 3.2 & 0.027 & 0.2676 \\
\hline 3 & 3.1 & 3.2 & 3.2 & 3.0 & 3.1 & 0.027 & 0.1281 \\
\hline 4 & 3.1 & 3.2 & 3.1 & 3.0 & 3.1 & 0.027 & 0.0719 \\
\hline 5 & $3.0^{\mathrm{AB}}$ & $3.2^{\mathrm{A}}$ & $3.1^{\mathrm{AB}}$ & $3.0^{\mathrm{B}}$ & 3.1 & 0.024 & 0.0097 \\
\hline 6 & 3.0 & 3.1 & 3.1 & 3.0 & 3.0 & 0.024 & 0.0751 \\
\hline Mean & $3.1^{\mathrm{A}}$ & $3.2^{\mathrm{A}}$ & $3.2^{\mathrm{A}}$ & $3.0^{\mathrm{A}}$ & 3.1 & 0.011 & 0.0752 \\
\hline SEM & 0.024 & 0.022 & 0.021 & 0.022 & & & \\
\hline Variation & -0.26 & -0.26 & -0.30 & -0.30 & -0.28 & 0.021 & 0.7774 \\
\hline SEM & 0.036 & 0.046 & 0.045 & 0.039 & & & \\
\hline
\end{tabular}

Effects of treatment $\times$ time: $P=0.7754$; time: $P=0.0001$; linear: $P=0.0001$; quadratic: $P=0.0001$

$\mathrm{C}=$ control; $\mathrm{DR}=$ "drench"; $\mathrm{CP}=$ calcium propionate; $\mathrm{PG}=$ propylene glycol; SEM=standard error of mean; $P=$ statistic probability; Variation=BCS difference between week 6 and week 1 .

Different superscript letters within each line differ by Tukey’s test at 5\%, whereas subscript letters differ at 10\%. 

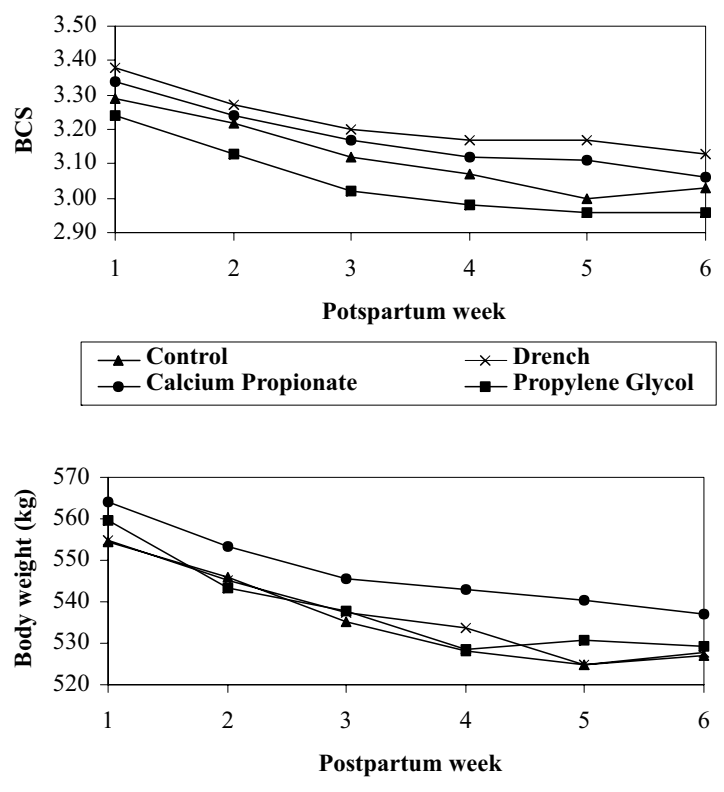

$\begin{array}{ll}\rightarrow-\text { Control } & - \text { Drench } \\ \rightarrow-\text { Calcium Propionate } & \rightarrow-\text { Propylene Glycol }\end{array}$
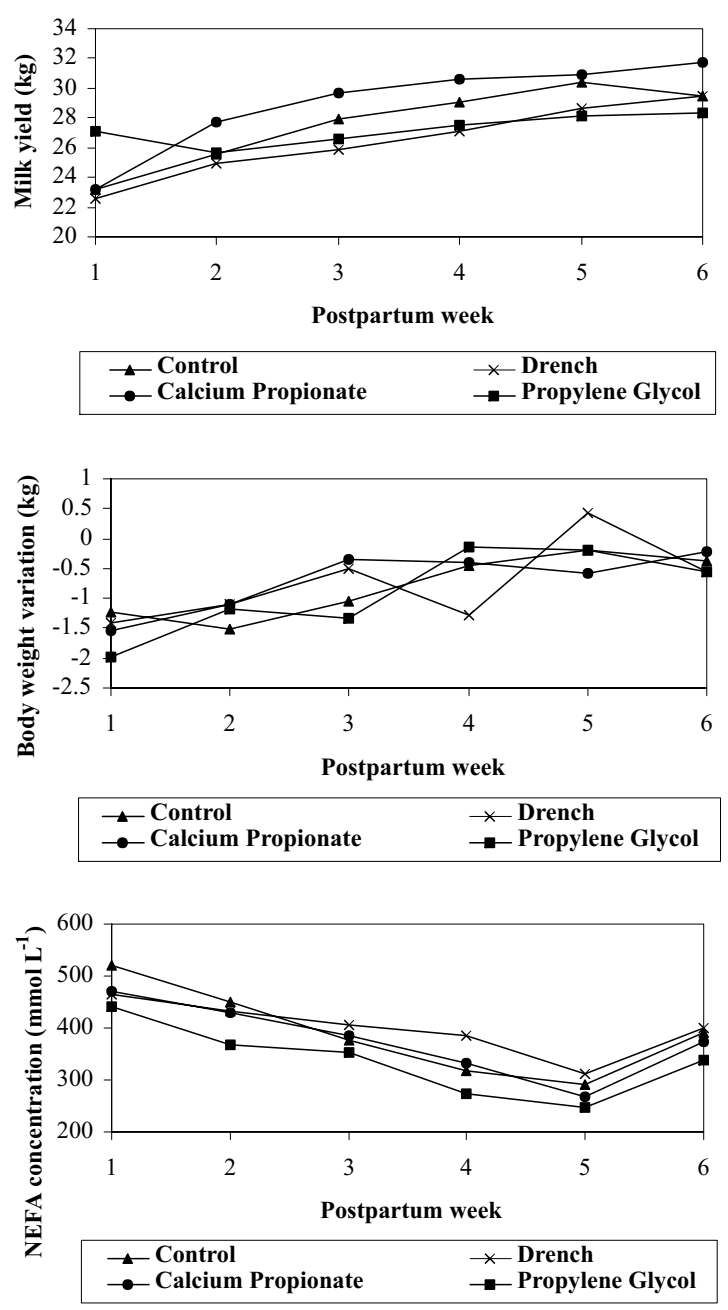

Figure 1 - Effect of treatments on body condition score (BCS), body weight and daily weight variation, milk yield, and nonesterified fatty acid concentration during the experimental period. body reserves is indispensable to maintain milk yield until the requirements are completely fulfilled by feed intake. Energy that comes from lipid mobilization can represent up to $33 \%$ of the energy used for milk synthesis (Moe, 1965). Komaragiri \& Erdman (1997) observed an average mobilization of $54 \mathrm{~kg}$ fat and $21 \mathrm{~kg}$ protein in Holstein cows, from 2 weeks prepartum until the $5^{\text {th }}$ week of lactation. In another study, Holcomb et al. (2001) seved postpartum weight losses of $38 \mathrm{~kg}$ for animals that, during the prepartum period, consumed concentrate diets in a restricted manner; therefore, those losses were almost $100 \%$ above the mean values observed in this experiment, even though their results were based on different diets and without energy supplementation.

On average, cows lost $0.79 \mathrm{~kg} \mathrm{day}^{-1}$ during the entire experimental period (Table 4 and Figure 1). For this variable, no interaction between time and treatment $(P=0.6252)$, nor a treatment effect $(P=0.6684)$, was observed. However, a quadratic effect of time $(P=0.0375)$ was verified on this variable, with the following equation: weight variation $=-2.180+0.6218$ week -0.0515 week $^{2}$. The inflexion point of this curve was verified approximately on the $42^{\text {nd }}$ day, or the $6^{\text {th }}$ week postpartum.

Buckley et al. (2000) observed that cows with high $(28.2 \mathrm{~kg})$ and medium $(25.0 \mathrm{~kg})$ genetic merits for milk yield experienced weight losses of 0.80 and $0.65 \mathrm{~kg}$ $\mathrm{day}^{-1}$, from the first to the fourth lactation week, respectively, which corresponds to approximately $22.4 \mathrm{~kg}$ for the first group and $18.2 \mathrm{~kg}$ for the second; these values are quite near to those obtained in this experiment.

Cows produced, on average, $27.3 \mathrm{~kg}$ milk day ${ }^{-1}$ (Table 5 and Figure 1) during the experiment, starting at $23.0 \mathrm{~kg}$ and finishing in the sixth week at $29.7 \mathrm{~kg}$. An interaction was verified between the main factors, time and treatment $(P=0.0076)$, for the variable under consideration. However, within each week, the analysis of variance did not detect any differences (Table 5 and Figure 1).

As time passed, yield increases were $12.5 \%$ in the second week relative to the first, $6.1 \%$ in the third week relative to the second, and so, with values of $3.8 \%, 3.4 \%$, and $0.8 \%$ (Table 5). The control, "Drench", and propylene glycol treatments showed a linear effect of time $(P=0.0001)$, and yield increases of $1.355,1.337$ and 0.999 $\mathrm{kg}$ were observed at each week, respectively. In turn, the calcium propionate treatment showed a quadratic effect with time $(P=0.0072)$.

Mean daily milk yield of animals supplemented with PG in this experiment was $26.5 \mathrm{~kg}$, which is lower than the $31.2 \mathrm{~kg}$ found by Miyoshi et al. (2001), who supplied the animals with the same PG dose $(500 \mathrm{~mL})$. Stokes \& Goff (2001) obtained mean values of 39.7, 41.1, and 42.8, for control, calcium propionate, and propylene glycol groups, respectively, using only two $300 \mathrm{~mL}$ PG doses and two $680 \mathrm{~g}$ calcium propionate doses. 
Table 3 - Effects of treatments on body weight and its variation during the experimental period.

\begin{tabular}{|c|c|c|c|c|c|c|c|}
\hline \multirow[b]{2}{*}{ Week } & \multicolumn{4}{|c|}{ Treatment } & \multirow[b]{2}{*}{ Mean } & \multirow[b]{2}{*}{ SEM } & \multirow[b]{2}{*}{$P$} \\
\hline & $\mathrm{C}$ & DR & $\mathrm{CP}$ & PG & & & \\
\hline & 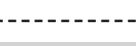 & $\cdots$ & $\cdots-\cdots-k$ & 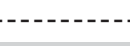 & $\cdots$ & $\cdots-\cdots$ & \\
\hline 1 & 554.6 & 555.0 & 563.9 & 559.5 & 558.2 & 5.338 & 0.7567 \\
\hline 2 & 546.0 & 545.1 & 553.2 & 543.5 & 546.8 & 5.418 & 0.7374 \\
\hline 3 & 535.3 & 537.4 & 545.5 & 537.8 & 538.9 & 5.476 & 0.7282 \\
\hline 4 & 528.0 & 533.8 & 543.1 & 528.4 & 533.2 & 5.428 & 0.7893 \\
\hline 5 & 524.8 & 524.9 & 540.3 & 530.7 & 530.0 & 5.413 & 0.9353 \\
\hline 6 & 527.0 & 527.9 & 537.2 & 529.3 & 530.2 & 5.295 & 0.7924 \\
\hline Mean & 536.0 & 537.3 & 547.2 & 538.3 & 539.6 & 2.221 & 0.8698 \\
\hline SEM & 4.515 & 5.181 & 3.546 & 4.243 & & & \\
\hline Variation & -31.2 & -27.1 & -29.1 & -30.7 & -29.5 & 2.141 & 0.9048 \\
\hline SEM & 4.510 & 4.653 & 4.314 & 4.499 & & & \\
\hline
\end{tabular}

Effects of treatment $\times$ time: $P=0.8223$; time: $P=0.0001$; linear: $P=0.0001$; quadratic: $P=0.0001$

$\mathrm{C}=$ control; $\mathrm{DR}=$ "drench"; $\mathrm{CP}=$ calcium propionate; $\mathrm{PG}=$ propylene glycol; SEM=standard error of mean; $P=$ statistic probability; Variation=weight difference between week 6 and week 1

Table 4 - Effects of treatments on the daily variation in body weight during the experimental period.

\begin{tabular}{|c|c|c|c|c|c|c|c|}
\hline \multirow[b]{2}{*}{ Week } & \multicolumn{4}{|c|}{ Treatment } & \multirow[b]{2}{*}{ Mean } & \multirow[b]{2}{*}{ SEM } & \multirow[b]{2}{*}{$P$} \\
\hline & $\mathrm{C}$ & DR & $\mathrm{CP}$ & $P G$ & & & \\
\hline & ---- & --.-- & - & -1 & 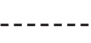 & 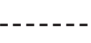 & \\
\hline 1 & -1.23 & -1.41 & -1.53 & -1.97 & -1.54 & 0.208 & 0.3761 \\
\hline 2 & -1.52 & -1.11 & -1.11 & -1.18 & -1.23 & 0.174 & 0.6577 \\
\hline 3 & -1.04 & -0.51 & -0.34 & -1.34 & -0.82 & 0.169 & 0.1640 \\
\hline 4 & -0.46 & -1.27 & -0.40 & -0.15 & -0.57 & 0.186 & 0.1686 \\
\hline 5 & -0.20 & 0.42 & -0.59 & -0.20 & -0.13 & 0.193 & 0.3753 \\
\hline 6 & -0.37 & -0.55 & -0.23 & -0.56 & -0.43 & 0.199 & 0.9589 \\
\hline Mean & -0.81 & -0.74 & -0.71 & -0.91 & -0.79 & 0.078 & 0.6684 \\
\hline SEM & 0.157 & 0.143 & 0.158 & 0.187 & & & \\
\hline
\end{tabular}

Effects of treatment $\times$ time: $P=0.6252$; time: $P=0.0001$; linear: $P=0.0001$; quadratic: $P=0.0375$

$\mathrm{C}=$ control; $\mathrm{DR}=$ ="drench"; $\mathrm{CP}=$ calcium propionate; $\mathrm{PG}=$ propylene glycol; $\mathrm{SEM}$ =standard error of mean; $P=$ statistic probability.

Table 5 - Effects of treatments on milk yield during the experimental period.

\begin{tabular}{|c|c|c|c|c|c|c|c|}
\hline \multirow[b]{2}{*}{ Week } & \multicolumn{4}{|c|}{ Treatment } & \multirow[b]{2}{*}{ Mean } & \multirow[b]{2}{*}{ SEM } & \multirow[b]{2}{*}{$P$} \\
\hline & $\mathrm{C}$ & DR & $\mathrm{CP}$ & PG & & & \\
\hline 1 & 23.2 & 22.6 & 23.2 & 27.1 & 23.0 & 0.538 & 0.9229 \\
\hline 2 & 25.5 & 24.9 & 27.7 & 25.6 & 25.9 & 0.566 & 0.7539 \\
\hline 3 & 27.9 & 25.9 & 29.7 & 26.6 & 27.5 & 0.547 & 0.2437 \\
\hline 4 & 29.0 & 27.0 & 30.6 & 27.5 & 28.5 & 0.532 & 0.2494 \\
\hline 5 & 30.4 & 28.7 & 31.0 & 28.1 & 29.5 & 0.540 & 0.3075 \\
\hline 6 & 29.5 & 29.5 & 31.7 & 28.4 & 29.7 & 0.551 & 0.3500 \\
\hline Mean & 27.6 & 26.4 & 29.0 & 26.5 & 27.3 & 0.235 & 0.5843 \\
\hline SEM & 0.530 & 0.474 & 0.450 & 0.398 & & & \\
\hline
\end{tabular}

Effects of treatment $\times$ time: $P=0.0076$; time: $P=0.0001$; linear: $P=0.0001$; quadratic: $P=0.0019$

$\mathrm{C}=$ control; $\mathrm{DR}=$ "drench"; $\mathrm{CP}=$ calcium propionate; $\mathrm{PG}=$ propylene glycol; $\mathrm{SEM}$ =standard error of mean; $\mathrm{P}=$ statistic probability. 
Similar results as those obtained in the present experiment were found by Studer et al. (1993) and Juchem (2000); their results did not show a PG effect, when supplied in the prepartum period, on milk yield. However, Fonseca (1997) observed higher milk yields only in the fourth and fifth lactation weeks for cows that received PG pre and postpartum. Sauer et al. (1973) and Formigoni et al. (1996) showed that a potential benefit conferred by PG would be expressed in a more consistent way under risk situations, as is the case with cows having an extreme body condition, a fact that did not occur in this experiment.

With regard to plasma concentrations of nonesterified fatty acids, no interaction of effects time $\times$ treatment was observed $(P=0.4791)$. Supplying of "drench", calcium propionate, and propylene glycol did not affect this variable $(P=0.4298)$. However, there was a linear effect of time effect $(P=0.0001)$ (Table 6 and Figure 1).

Mean NEFA concentration during the experimental period was $376.6 \mathrm{mmol} \mathrm{L}^{-1}$. In the week prior to calving, cows showed, on average, $420 \mathrm{mmol} \mathrm{L}^{-1}$ NEFA. In the first week postpartum, however, mean NEFA concentration increased to $474.7 \mathrm{mmol} \mathrm{L}^{-1}$. Mean NEFA value during the experiment decreased by $41 \%$ in the $5^{\text {th }}$ week postpartum, relatively to the first week, with a reduction of $48.24 \mathrm{mmol} \mathrm{L}^{-1}$ per week.

Peripartum period is marked by striking alterations, some of which are medium-term, as is the case with blood concentrations of NEFA (weeks). Nonesterified fatty acids is the main energy source during the end of gestation and beginning of lactation (Drackley, 1998), acting as a glucose-saving mechanism, i.e., the peripheral tissues use NEFA rather than glucose and amino acids. Plasma concentrations of NEFA follow a growing pattern starting on the third prepartum week, with a peak near calving, decreasing through lactation. Values obtained in this study are within the limits found by other researchers. Vasquez-Añon et al. (1994) found
$300 \mathrm{mmol} \mathrm{L}^{-1}$ on day -10 from calving, and 1014, 700, 445 , 320, and $300 \mathrm{mmol} \mathrm{L}^{-1}$ on days zero, five, 10, 20, and 25 postpartum, respectively.

Staples et al. (1990) did not find interaction effect between time and treatment, and observed a decrease in NEFA concentrations from the first week in relation to the ninth, with values of $612 \mathrm{mmol} \mathrm{L}^{-1}$ and $237 \mathrm{mmol}$ $\mathrm{L}^{-1}$, respectively. In the same experiment, those authors related the effect of NEFA concentrations on ovarian activity and observed that NEFA concentrations were not a good indicator of energy status. Juchem (2000) did not find a PG effect $(300 \mathrm{~mL})$, nor a treatment $\times$ time interaction, on the NEFA concentrations in the pre and postpartum periods, when the product was supplied in the prepartum period. Then again, Fonseca (1997) did not observe a PG effect during the prepartum period and the beginning of lactation $(300 \mathrm{~mL})$, on the concentrations of NEFA and glucose, and on the incidence of subclinical ketosis. However, Studer et al. (1993) demonstrated a decrease in FFA during prepartum and a reduction tendency in the postpartum, by supplying 1 L PG per day during prepartum. Waldo \& Schultz (1960) concluded that the hyperglycemic effect of PG was a consequence, for the most part, of its intact absorption and, to a lesser extent, of the production of propionic acid, and therefore it was an excellent alternative for treating clinical cases of ketosis.

Goff et al. (1996), supplying calcium propionate at calving and after 12 hours, observed a smaller concentration of NEFA 24 hours after calving in Jersey cows, but not in Holstein cows. However, its application reduced the occurrence of milk fever and subclinical hypocalcemia in both breeds, in herds where those problems occurred.

The cows in the present experiment, in both farms, were submitted to good nutritional management in the prepartum and postpartum periods. This can be demonstrated from the lack of occurrence of animals showing clinical ketosis, and from the NEFA concentrations,

Table 6 - Effects of treatments on the concentrations of nonesterified fatty acids during the experimental period.

\begin{tabular}{|c|c|c|c|c|c|c|c|}
\hline \multirow[b]{2}{*}{ Week } & \multicolumn{4}{|c|}{ Treatment } & \multirow[b]{2}{*}{ Mean } & \multirow[b]{2}{*}{ SEM } & \multirow[b]{2}{*}{$P$} \\
\hline & $\mathrm{C}$ & DR & $\mathrm{CP}$ & PG & & & \\
\hline \multicolumn{8}{|c|}{ - } \\
\hline 1 & 521.0 & 464.7 & 470.6 & 440.8 & 474.7 & 18.044 & 0.3118 \\
\hline 2 & 449.9 & 433.3 & 428.2 & 369.0 & 420.0 & 15.742 & 0.3186 \\
\hline 3 & 377.9 & 405.0 & 386.1 & 352.8 & 380.4 & 15.030 & 0.9228 \\
\hline 4 & 317.5 & 385.7 & 331.2 & 274.0 & 327.1 & 15.051 & 0.1791 \\
\hline 5 & 291.6 & 312.7 & 267.2 & 248.0 & 279.9 & 11.369 & 0.4900 \\
\hline Mean & 392.2 & 401.3 & 374.4 & 338.4 & 376.6 & 7.218 & 0.4298 \\
\hline SEM & 14.832 & 14.262 & 12.605 & 11.084 & & & \\
\hline
\end{tabular}

Effects of treatment $\times$ time: $P=0.4791$; time: $P=0.0001$; linear: $P=0.0001$; quadratic: $P=0.1471$

$\mathrm{C}=$ control; $\mathrm{DR}=$ "drench"; $\mathrm{CP}=$ calcium propionate; $\mathrm{PG}=$ propylene glycol; $\mathrm{SEM}$ =standard error of mean; $\mathrm{P}=$ statistic probability. 
which were relatively low when compared with other experiments. Similarly, no animals were diagnosed with milk fever.

There were no differences between treatments ( $P=0.7399)$ with regard to the first detectable postpartum estrus. On average, cows showed the first estrus at 69.5 days postpartum (Table 7 and Figure 2). This result was superior to that obtained by Thatcher \& Wilcox (1973), of 43 days, and by Miyoshi (1995), who found 53.1 days for animals that received $500 \mathrm{~mL}$ propylene glycol, and 56.8 days for animals in the control group. Likewise, Jorritsma et al. (2000) observed a 54.1 day interval for the first estrus, without administration of energy supplements.

In Brazil, Fonseca (1997) recorded a mean value of 40.33 days for the first estrus in animals with normal concentrations, and of 51.6 days in animals with acetonemia; these are values still lower than the 69.5 days found in this trial. However, that author did not find a PG effect on that variable, either. More expressive results, but also inferior than those found in the present study, were recorded by Juchem (2000), with means of 22.2 days until the first ovulation for animals that received propylene glycol, and 18.6 days for animals in the control group, detected by ultrasound. Also, the observed percentages of anestrus cows were $7 \%$ and $24 \%$, for PG and the control, respectively. The difference, however, was not significant, suggesting that under adequate management conditions the potential benefit of this additive could be small, therefore making its use unviable due to its high cost. Nevertheless, Formigoni et al. (1996) found smaller percentages of anestrus cows (30 and 58\%) at 90 days of lactation for cows receiving PG at pre and postpartum.

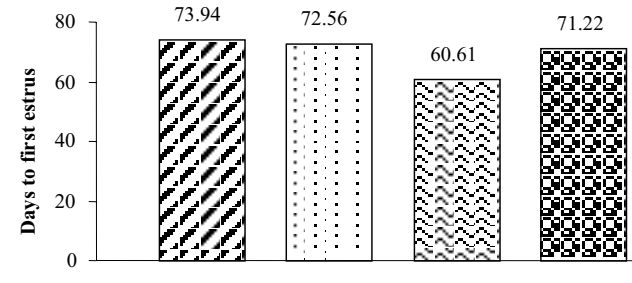

Treatments

๑Control $\square$ Drench @Calcium Propionate

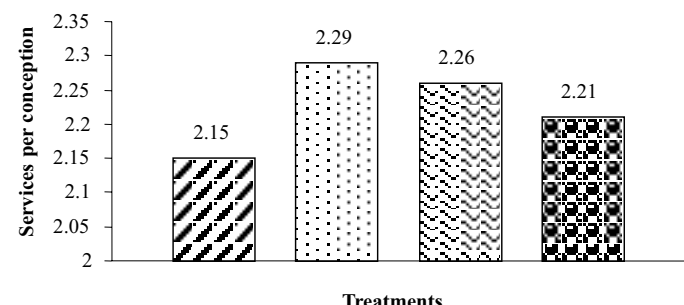

$\square$ Control $\square$ Drench $\square$ Calcium Propionate $\quad$ Propylene Glycol

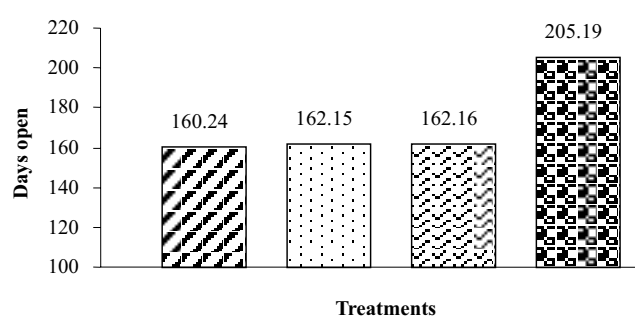

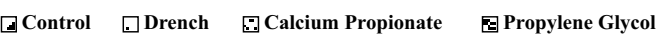

Figure 2 - Effects of treatments on the number of days to first estrus, number of services per conception, and number of days open.

Table 7 - Effect of treatments on number of days to the first estrus, service per conception, and days open during the experimental period.

\begin{tabular}{|c|c|c|c|c|c|c|c|}
\hline \multirow[b]{2}{*}{ Variable } & \multicolumn{4}{|c|}{ Treatment } & \multirow[b]{2}{*}{ Mean } & \multirow[b]{2}{*}{ SEM } & \multirow[b]{2}{*}{$P$} \\
\hline & $\mathrm{C}$ & DR & $\mathrm{CP}$ & $P G$ & & & \\
\hline \multicolumn{8}{|c|}{ days } \\
\hline $1^{\text {st }}$ estrus & 73.9 & 72.6 & 60.6 & 71.2 & 69.5 & 2.790 & 0.7399 \\
\hline SEM & 6.087 & 5.146 & 4.607 & 6.388 & & & \\
\hline $\mathrm{n}$ & 35 & 39 & 38 & 37 & & & \\
\hline \multicolumn{8}{|c|}{ Services per conception } \\
\hline $\mathrm{S} / \mathrm{C}$ & 73.9 & 72.6 & 60.6 & 71.2 & 69.5 & 2.790 & 0.7399 \\
\hline SEM & 6.087 & 5.146 & 4.607 & 6.388 & & & \\
\hline $\mathrm{n}$ & 35 & 39 & 38 & 37 & & & \\
\hline \multicolumn{8}{|c|}{ days } \\
\hline Days open & 160.2 & 162.2 & 162.2 & 205.2 & 172.6 & 11.556 & 0.8874 \\
\hline SEM & 23.406 & 16.958 & 19.128 & 30.886 & & & \\
\hline $\mathrm{n}$ & 29 & 33 & 32 & 32 & & & \\
\hline
\end{tabular}

$\mathrm{C}=$ control; $\mathrm{DR}=$ "drench"; $\mathrm{CP}=$ calcium propionate; $\mathrm{PG}=$ propylene glycol; $\mathrm{SEM}=$ standard error of mean; $P=$ statistic probability, $1^{\text {st }}$ estrus= number of days to the first estrus; $\mathrm{S} / \mathrm{C}=$ number of services per conception; Days open= number of days open; $n=$ number of samples for each variable. 
Mean number of services per pregnancy was 2.2, with no difference $(P=0.9342)$ among treatments (Table 7 and Figure 2). Lower values were found by Miyoshi (1995), of 1.7 service per conception (S/C), in animals also supplemented with $500 \mathrm{~mL}$ of propylene glycol. Higher values than those obtained in this experiment were found by Smith \& Wallace (1998), with 2.7 S/C for cows that cycled before postpartum day 21; by Heuwieser et al. (1994), with 3.3 services per conception in animals with less days for the first service and lower yields; and by Foote \& Riek (1999), with 2.6 services per conception for cows showing some reproductive problem.

The number of services per conception is a variable that results from a well-done heat verification, a wellconducted and successful insemination, a good fertilization rate and a low early embryonic death rate (Ayalon, 1978). The number of services per conception obtained in this experiment was relatively high, since a S/C value of 2.0 is considered normal or acceptable. The higher value obtained (2.3) could be due to an association of the factors mentioned above, and to the fact that repeat breeder cows were not excluded in the statistical analysis.

On average, in this experiment, number of days open was 172.6 (Table 7 and Figure 2). This variable was not affected $(P=0.8874)$ by the treatments. Smaller number of days open (95.5 days) was found by Miyoshi (1995) for a cow group receiving $500 \mathrm{~mL}$ of propylene glycol (111.5 days for the control group). In a survey conducted in four farms, Heuwieser et al. (1994) found 148.7, 111.5, 120.6, and 104 days open. In Brazil, during a survey conducted at Zona da Mata (Forest Zone) in Minas Gerais, Ferreira et al. (1984) verified a mean of 240 days open in 1,634 cows without supplementation. Current reproduction data indicate that heat detection problems might have occurred in those farms.

\section{REFERENCES}

ARBEL, R.; BIGUN, Y.; EZRA, E.; STURMAN, H.; HOJMAN, D. The effect of extended calving intervals in high - yielding lactating cows on milk production and profitability. Journal of Dairy Science, v.84, p.600-608, 2001.

ASLUP, D.; SCHLATTER, L. Parity differences in a controlled nutrocal study in a California dairy. Des Moines: Kemin Industries 1998. p.14 (Technical Information).

ASSOCIATION OF OFFICIAL ANALYTICAL CHEMISTS. Official methods of analysis of the AOAC. 15.ed. Washington: AOAC, 1985. 1015p.

AYALON, N. A review of embrionic mortality in cattle. Journal of Reproduction and Fertility, v.54, p.483-493, 1978.

BUCKLEY, F.; DILLON, P.; RATH, M.; VEERKAMP, R.F. The relationship between genetic merit for yield and live weight, condition score, and energy balance of spring calving Holstein Friesian dairy cows on grass based system of milk production. Journal of Dairy Science, v.3, p.18781886, 2000.

BUTLER, W.R.; CANFIELD, R.W. Interrelationships between energy and postpartum reproduction. In: CORNELL NUTRITION CONFERENCE, Ithaca, 1989. Proceedings: Ithaca: Cornell University, 1989. p.66.
CHRISTENSEN, J.O.; GRUMMER, R.R.; RASMUSSEN, F.E.; BERTICS, J.S. Effect of method of delivery of propylene glycol on plasma metabolites of feed - restricted cattle. Journal of Dairy Science, v.80, p.563-568, 1997.

DRACKLEY, J.K. Nutritional management of dairy cows during the transition period. In: ANNUAL RUMINANT NUTRITION SYMPOSIUM, 13., Gainesville, 1998. Proceedings.

DRACKLEY, J.K. What about testing for blood NEFA levels in fresh cows? Hoard's Dairyman, v.144, p.783, 1999.

FERREIRA, A.M.; SÁ, W.F.; VILA, C.H.A.; ASSIS, A.G. Diagnóstico da situação produtiva e reprodutiva em rebanhos leiteiros da zona da MataMG. In: CONGRESSO BRASILEIRO DE MEDICINA VETERINÁRIA, Belém, PA. v.19, p.61, 1984.

FONSECA, L.F.L. Suplementação de propileno glicol para vacas leiteiras periparturientes: efeitos sobre o metabolismo, condição corporal, produção e reprodução. São Paulo: USP/FMVZ, 1997. 114p. (Tese Doutorado).

FORMIGONI, A.; CORNIL, M.C.; PRANDI, A.; MORDENTI, A.; ROSSI, A.; PORTEDELLE, D.; RENAVILLE, R. Effect of propylene glycol supplementation around parturition on milk yield, reproduction performance and some hormonal and metabolic characteristics in dairy cows. Journal of Dairy Research, v.63, p.11-24, 1996.

FOOTE, R.H.; RIEK, P.M. Gonadotropin-releasing hormone improves reproductive performance of dairy cows with slow involution of the reproductive tract. Journal Animal Science, v.77, p.12-16, 1999.

GEARHART, M.A.; CURTIS, C.R.; ERB, H.N.; SMITH, R.D.; SNIFFEN, C.J.; CHASE, L.E.; COOPER, B.D. Relationship of changes in condition score to cow health in Holsteins. Journal of Dairy Science, v.73, p.31323140, 1990

GOFF, J.P.; HORST, R.L.; JARDON, P.W.; BORELLI, C.; WEDAM, J. Field trials of an oral calcium propionate paste as an aid to prevent milk fever in periparturient dairy cows. Journal of Dairy Science, v.79, p.378-383, 1996.

GRUMMER, R.R. Impact of changes in organic nutrient metabolism on feeding the transition dairy cow. Journal of Animal Science, v.73, p.2820-2833, 1995.

GRUMMER, R.R.; WINKLER, J.C.; BERTICS, S.J.; STUDER, V.A. Effect of propylene glycol dosage during feed restriction on metabolites in blood of prepartum Holstein heifers. Journal of Dairy Science, v.77, p.36183628, 1994.

HEUWIESER, W.; FERGUSON, J.D.; GUARD, C.L.; FOOT, R.H.; WARNICK, L.D.; BREICKNER, L.C. Relationship between administration of GnRH, body condition score and fertility in Holstein dairy cattle. Theriogenology, v.42, p.703-714, 1994.

HOLCOMB, C.S.; VAN HORN, H.H.; HEAD, H.H.; HALL, M.B.; WILCOX, C.J. Effects of prepartum dry matter intake and forage percentage on postpartum performance of lactating dairy cows. Journal of Dairy Science, v.84, p.2051-2058, 2001.

JORRITSMA, R.; JORRITSMA, H.; SCHUKKEN, Y.H.; WENTINK, G.H. Relationship between fatty liver and fertility and some periparturient diseases in commercial Dutch dairy herds. Theriogenology, v.54, p.1065-1074, 2000.

JUCHEM, S.O. Suplementação de propileno glicol e monensina sódica para vacas no período de transição. Piracicaba: USP/ESALQ, 2000. 99p. (Dissertação - Mestrado).

KOMARAGIRI, M.V.S.; ERDMAN, R.A. Factors affecting body tissue mobilization in early lactation dairy cows.1. Effect of dietary protein on mobilization of body fat and protein. Journal of Dairy Science, v.80, p.929-937, 1997.

MIYOSHY, S. Role of energy balance, plasma glucose and insulin on ovarian function and conception of dairy cows. Ames: Ohio State University, 1995. 82p. (Thesis - M.S.).

MIYOSHI, S.; PATE, J.L.; PALMQUIST, D.L. Effects of propylene glycol drenching on energy balance, plasma glucose, plasma insulin, ovarian function and conception in dairy cows. Animal Reproduction Science, v.68, p.29-43, 2001.

MOE, P.W. Effects of level of intake on the utilization of diets by dairy. Ithaca: Cornell University, 1965. (Thesis - Doctor).

NATIONAL RESEARCH COUNCIL. Nutrient requirements of dairy cattle. Washington: National Academy of Science, 2001. 381p. 
NEBEL, L.R.; McGILLARD, M.L. Interaction of high yield and reproductive performance in dairy cows. Journal of Dairy Science, v.76, p.3257-3268, 1993.

PHILIPSON, J. Impact of international trade in cattle, semen and embryos on genetics evaluation. In: INTERNATIONAL DAIRY CONGRESS, 23., Montreal, 1990. Brussel: International Dairy Federation, 1990. p.644.

RUKKWAMSUK, T.; WENSING, T.; MATT, G.J H. Effect of overfeeding during dry period on regulation of adipose of dairy tissue metabolism in dairy cows during the periparturient period. Journal of Dairy Science, v.81, p.2904-2911, 1998.

SAS INSTITUTE. SAS user's guide: statistic. 5.ed. Cary, 1985.

SAUER, F.D.; ERFLE, J.D.; FISHER, L.J. Propylene glycol and glycerol as a feed additive for lactating dairy cows: an evaluation of blood metabolic parameters. Canadian Journal of Animal Science, v.53, p.265-271, 1973.

SCHLATTER, L. The addition of Nutrocal to the diets of periparturient cows: a review. Des Moines: Kemin Industries, 1997. p.1-11. (Technical Information)

SMITH, M.C.A.; WALLACE, J.M. Influence of early postpartum ovulation on the reestablishment of pregnancy in multiparous and primiparous dairy cattle. Reproduction Fertility and Development, v.10, p.207216, 1998.

STAPLES, C.R.; THATCHER, W.W.; CLARK, J.H. Relationship between ovarian activity and energy status during the early postpartum period of high producing dairy cows. Journal of Dairy Science, v.73, p.938947, 1990.
STOKES, R.S.; GOFF, J.P. Case study: evaluation of calcium propionate and propylene glycol administrated in to esophagus of dairy cattle at calving. The Professional Animal Scientist, v.17, p.115-122, 2001.

STUDER, V.A.; GRUMMER, R.R.; BERTICS, S.J. Effect of prepartum propylene glycol administration on periparturient fatty liver in dairy cows. Journal of Dairy Science, v.76, p.2931-2939, 1993.

THATCHER, W.W.; WILCOX, C.J. Postpartum estrus as an indicator of reproductive status in the dairy cow. Journal of Dairy Science, v.56, p.608-610, 1973.

VAN SOEST, P.J.; ROBERTSON, J.B.; LEWIS, B.A. Methods for dietary fiber, neutral detergent fiber, and non-starch polysaccharides in relation to animal nutrition. Journal of Dairy Science, v.74, p.3583-3597, 1991.

VAZQUEZ-AÑON, M.; BERTICS, S.; LUCK, M.; GRUMMER, R.R. Peripartum liver triglyceride and plasma metabolites in dairy cows. Journal of Dairy Science, v.77, p.1521-1528, 1994.

WALDO, D.R.; SCHULTZ, L.H. Blood and rumen changes following the intraruminal administration of glycogenic materials. Journal of Dairy Science, v.43, p.496-505, 1960.

WILDMAN, E.E.; JONES, G.M.; WAGNER, P.E.; BOWMAN Jr. R.L.; TROUTT, H.F.; LESCH, T.N. A dairy cow body condition scoring system and its relationship selected production characteristics. Journal of Dairy Science, v.65, p.495-501, 1982.

Received September 27, 2003

Accepted June 15, 2004 